\title{
Rent Generation Under the Norwegian Rights-Based Pelagic Fishery
}

\author{
Bernt A. Bertheussen* and Terje Vassdal \\ School of Business and Economics, UiT The Arctic University of Norway, Tromsø, Norway
}

As a general rule, only active fishermen can own fishing boats for commercial fishing in Norway. Thus, vertical integration is not allowed. Accordingly, the Norwegian empirical context is exceptionally well suited to study actual rent creation as a potential resource rent can only accrue to the catch stage of the value chain. This paper examines profitability and rent generation of 35 seagoing Norwegian purse seiners (around half the population) for 13 consecutive years. The study period starts in 2005, which saw the introduction of the latest version of the Norwegian individual transferable quota (ITQ) variant, or the so-called structural quota (SQ) system. First, this study investigates how profitable a purse seiner has become during the $S Q$ regime. As per our findings, it was

\section{OPEN ACCESS}

Edited by:

Di Jin,

Woods Hole Oceanographic Institution, United States

Reviewed by:

Andrew Michael Carr-Harris, Northeast Fisheries Science Center (NOAA), United States Andrew Ropicki, University of Florida, United States

*Correspondence:

Bernt A. Bertheussen bernt.bertheussen@uit.no

Specialty section: This article was submitted to Marine Affairs and Policy, a section of the journal Frontiers in Marine Science

Received: 22 December 2021 Accepted: 08 February 2022 Published: 01 March 2022

Citation: Bertheussen BA and Vassdal T (2022) Rent Generation Under the Norwegian Rights-Based Pelagic Fishery. Front. Mar. Sci. 9:841505. doi: 10.3389/fmars.2022.841505 found that the average annual return on equity $(R O E)$ was $20.8 \%$ and that the book value of equity more than doubled over the period (a 166\% increase). Moreover, for the cohort of 35 vessels, rent operationalized as residual income (RI) was reported for every year examined (2006-2017). The discounted value of RI for the period was approximately 50 million NOK per vessel, which is equivalent to about 5 million EUR. This implies that the players generated substantial rent. The findings of this study draw a picture of a financially stable and lucrative industry. Finally, implications of the findings are discussed.

Keywords: residual income, resource rent, profitability, pelagic fishery, Norway

\section{INTRODUCTION}

Historically, the Norwegian welfare state has been partly financed by resource rent taxes imposed on power stations and oil and gas enterprises (Sanders et al., 2016; Moses and Letnes, 2017). Fuglestad and Almås (2021, p. 211) claim that, "resource rent tax on oil production has greatly benefited the whole Norwegian population for decades" (authors translation). The recent official Norwegian report on taxation of aquaculture activities (NOU [2019: 18], 2019) stated that the Norwegian society has a legitimate claim for a share of the excess return from private actors who receive exclusive rights to exploit scarce and valuable common owned natural resources. Accordingly, the report proposed to introduce a resource rent tax on the aquaculture industry. However, this proposal was rejected in the Norwegian Parliament ("Storting") ( $\mathrm{Am}, 2021$ ).

Nevertheless, resource rent taxes add considerable annual proceeds to the Norwegian Treasury. The general tax rate for Norwegian limited companies is $22 \%$. This tax is calculated by net profit, and the rate is flat. The resource rent tax is an additional tax that oil and gas companies and power stations must pay. In 2019, this tax rate amounted to $56 \%$ in the petroleum sector; thus, in total, these companies had a tax rate of $78 \%$. The special tax on petroleum added an average of more than 
NOK $^{1} 100$ billion annually to the Norwegian Treasury in the period 2001-2020. ${ }^{2}$ The resource rent tax for hydroelectric power plants is $37 \%$. This special tax on hydroelectric power producers has contributed an extra NOK 4-6 billion annually to the government in recent years. ${ }^{3}$ With significant profits in the fish capture industry in recent years, perhaps especially in deep sea fishing (Flaaten et al., 2017; Bertheussen and Vassdal, 2019, 2021), this industry now also emerges as a resource rent tax candidate.

Resource rent taxes have the unusual attribute that they may both increase fairness and strengthen the governmental budget (Mirrlees et al., 2011). Furthermore, in contrast to taxes on labor income, resource taxes have a negligible effect on labor and investment incentives (Summers, 1987). In this study, we argue that research that is able to identify sources of such "good" governmental revenue has the potential to be extremely valuable at this time in history when a pandemic is straining public funds.

Investigating the existence of above-normal profit at the vessel level, which may form the basis of a resource rent tax is at the core of this study. Profit is defined as the amount the owners can dispose of after all the costs, including depreciations, amortizations, and interest on debt, which are deducted from income. Accounting profit is clearly stated in the companies' accounts, which contrasts with the concept above-normal profit. This paper defines above-normal profit in line with Magni (2009) as the surplus profit that remains after the opportunity cost of capital has been charged. That is, above-normal profit is used as a synonym for the business economics term RI or the more general term (economic) rent.

Residual income or economic rent may stem from diverse sources. For example, some firms may be extraordinary efficient (Barney, 1991), or they may have gained a favorable strategic position within the industry (Porter, 2008). Finally, resource rent may be a third source to above-normal profit for natural resource-based firms (Bertheussen and Vassdal, 2019). Resource rent describes the net economic benefit from exploiting a valuable scarce natural resource. It is calculated by subtracting all accrued production costs including the opportunity cost of capital, from the accrued revenue. Accordingly, one can interpret resource rent as the value of the natural resource.

The approach to capture and redistribute a fishery's resource rent to society will affect industry attractiveness; thus, the players prospect to reap extraordinary profit (Bertheussen and Vassdal, 2021). Internationally, there have been few attempts by governments to tax rents from fisheries (Hoshino et al., 2019). However, in 2004, Iceland introduced a fishing fee to cover the management and enforcement costs (Gunnlaugsson et al., 2018). The fee was soon increased to ensure that a share of the rent was being allocated to the public to encourage support for the ITQ approach taken. Without some redistribution institutions, i.e., taxation, the rent from fisheries accrues primarily to the quota owners (Flaaten et al., 2017).

\footnotetext{
${ }^{1}$ In October 2021, 10 NOK corresponded to approximately 1 EUR.

${ }^{2}$ https://www.norskpetroleum.no/okonomi/petroleumsskatt/

${ }^{3}$ https://energifaktanorge.no/regulering-av-energisektoren/skattlegging-avkraftsektoren/
}

The empirical context of this present study is the Norwegian seagoing pelagic fishing fleet. In 1968-1969, the industry experienced how the Atlanto-Scandian herring stock collapsed as a result of overharvesting in an open-access fishery (Bertheussen, 2022). In the two decades that followed, the industry was dependent on public subsidies while the herring stock was rebuilt. The rebuild was supported by total allowable catch (TAC) regulations, the introduction of barriers to entry, and exit incentives to reduce capacity. In the early 1990s, subsidies ceased. About the same time, the Norwegian individual vessel quota (IVQ) system was introduced. Since then, the industry has been profitable (Bertheussen and Vassdal, 2021). In 2005, a more market-oriented and flexible variant of the IVQ system was implemented, or the so-called structural quota system (SQ system).

In this present study, we aim to investigate whether the vessels have been able to generate profit and rent in the first 12 years (2005-2017) that followed after the introduction of the SQ regime. Accordingly, the following research question (RQ) is raised:

RQ: To what degree have the purse seiners that were present in the industry in 2005 been able to generate rent during the period in which the SQ system has been in operation?

Some studies have estimated actual resource rent in fisheries. For one, Greaker et al. (2017) found that the resource rent was negative in Norwegian fisheries in the 1980s and 1990s, but that it has been about zero in recent years. Nielsen et al. (2017) concluded that the pelagic fisheries in Faroe Islands, Denmark, Iceland, Norway, and the United Kingdom, which are all managed by different ITQ variants, are generating significant resource rent. Gunnlaugsson and Agnarsson (2019) found that there exists no resource rent in Iceland until 2008, but that since then annual rent averaged around $10-19 \%$ of the export value of the fishing industry.

As a general rule, only active fishermen can own fishing boats for commercial fishing in Norway. The rule expresses a basic principle in Norwegian fisheries policy, which is to have a fisher-owned fleet. Upstream vertical integration from the process stage to the catch stage is not allowed (Isaksen, 2007). Accordingly, a potential resource rent can then only accrue to the catch stage of the value chain. As the harvesting and the processing industries are strictly separated, a study of resource rent generation in a Norwegian context is particularly well suited. Absence of internal transfer pricing will clearly show where in the value chain actual resource rent is created. This may be in contrast to, for example, Icelandic fisheries, where the catch stage and processing stage operate in vertical integrated value chains (e.g., Byrne et al., 2019). However, in the cod fisheries exceptions have been made to the general rule on fisher-owned vessels. In this particular sector some land-based processing plants have granted permission to own seagoing bottom trawlers (Isaksen, 2007). This article proceeds as follows. The next section describes the theoretical argument of this study and thereafter the context. Next, the research design, method, and data are 
presented before the findings. The paper ends with a discussion of the empirical findings.

\section{THEORETICAL PERSPECTIVE}

Most commercial fisheries are managed by and through institutions (North, 1990; Holm, 1995; Jentoft, 2004; Vatn, 2005). Closures of the commons, introduction of the TAC quotas to protect the stock of fish, implementation of barriers to industry entry, and catch share system to reduce overcapacity and secure vessel profitability are all examples of institutional measures aiming at making fisheries biologically and economically sustainable. Once the required institutional framework is in place, fishing is expected to generate profit for incumbent vessels (Arnason, 2008; Costello et al., 2008). In a well-regulated fishery, the fishing industry can expect to earn more than the other industries because of particularly favorable institutional framework conditions (Bertheussen, 2021). Thus, this study will especially highlight the high barriers to entry a commercial fishery, and the lack of rivalry between the players both in the raw material market, and in a Norwegian context, in the product market.

\section{High Entry Barriers}

Historically, fish resources belong collectively to the people of Norway. Every Norwegian citizen has, therefore, traditionally been allowed to equip a vessel, and establish himself as a fisher. But in the decades after the World War II, stocks were increasingly exposed to overfishing due to increased fishing capacity and more efficient fishing technology. The free fishing (open access) of pelagic species such as herring, mackerel, and capelin lasted until 1970 (Hersoug, 2005). Meanwhile, free fishing of cod and other demersal fish species was halted in 1989 (Holm et al., 2014). Authorities were forced to introduce barriers to entry into fisheries to avoid the tragedy of the commons (Gordon, 1954; Hardin, 1968; Dietz et al., 2003). Initially, in the 1930s, it was decided that only active Norwegian fishers were allowed to establish trawler companies. This provision was later extended to all fisheries. Without Norwegian citizenship, you cannot fish on a Norwegian controlled fish stock. The Participant Act is still seen as a mainstay in Norwegian fisheries policy (Jentoft and Finstad, 2018). It is this law that refuses onshore facilities to own fishing boats with quotas. In this way, the fishers are protected from being vertically integrated with the fish buyers (Isaksen, 2007).

To prevent overfishing, the most important commercial fisheries have been closed to new entrants. The closure led to strict formal requirements for new shipping companies that wanted to establish themselves in the industry (Bertheussen et al., 2021). Instead of stimulating new establishments and a market characterized by free competition, fisheries politicians have been concerned with getting as many vessel owners as possible to exit fishing, as it is difficult to ensure ecologically sustainable stocks in an industry characterized by significant overcapacity. Overcapacity also provides a poor basis for business profitability (Bertheussen et al., 2020). The good profitability of the fish capture industry in recent years may tempt some to establish themselves in this industry with their own boat and quota. However, the very high legal and financial barriers to entry contribute to curbing competition from intruders (Bertheussen et al., 2021). Fishers are therefore protected from competition from the outside.

\section{No Rivalry}

Before Norwegian fisheries were closed about 50 years ago, an important issue for the individual fisher was to catch as much of the available natural resource as possible. Fishing was at this time described as "Olympic" due to the strong internal competition among fishers (Birkenbach et al., 2017). The competition for limited natural resources inevitably led to overfishing and decimation of the stocks. Thus, to address this problem, fisheries were closed, and total quotas (TAC quotas) were introduced to protect fish stocks from the "tragedy of the commons." Such a tragedy occurs when fishers are unable to stop fishing for a stock (Gordon, 1954; Hardin, 1968; Dietz et al., 2003). In Norway, the total quotas for the individual species were distributed to the vessels free of charge based on the vessels' historical catch volumes (Johnsen and Jentoft, 2018). Eventually, the vessel quotas were made tradable anticipating that this feature would incentivize the fishers to reduce their excess catch capacity (Grafton, 1996; Standal and Asche, 2018).

The closure and introduction of total quotas have contributed to a significant increase in value creation in the fisheries in the last two decades (Bertheussen and Vassdal, 2021). Norwegian fisheries were heavily subsidized, especially in the 1970s and 1980s (Flaaten, 2021). The great values that are now created by ecologically and financially sustainable fishing are today distributed to far fewer fishers than before (National Audit Office, 2020). This has contributed to a significant profit, which is reflected in very high quota prices (Hannesson, 2017; Bertheussen et al., 2021). Through the quota, which a vessel has at its disposal, an institutionally protected share of the raw material market has been allocated (Grafton, 1996).

\section{Fishers Selling Power}

Through legislation, the fishers have been allowed to establish their own sales monopolies. At the inception of this legislation, in 1929 (herring) and 1938 (cod fisheries), the fishers were significantly disadvantaged in the bargaining with local fish buyers. The fisher population was considered to be poor, like in many developing countries still today. Through these institutions, the fishers have gained a more balanced bargaining power toward fish buyers (Hersoug et al., 2015). The monopolies have given fishers an exclusive right to set the minimum price for the fish they land if they are unable to agree through central negotiations with the buyers. The sales monopolies also refuse fishers to sell their catches through other outside channels, to the extent that fish is sold at auctions; commonly, the auction platform is owned and operated by fisher-owned sales organizations (Sogn-Grundvåg et al., 2019). The legislative sales monopolies mean that fishers never have to compete in their product markets. The monopolies provide fishers with significant market power in relation to buyers (Hersoug et al., 2015). 


\section{Summary}

The Norwegian capture stage of the seafood value chain enjoys attractive institutional framework conditions (Bertheussen, 2021; Bertheussen and Vassdal, 2021). This may apply in particular to the deep-sea fishing fleet for whitefish and the corresponding fleet for pelagic fish. After extensive structuring, there are today only about 30 seagoing whitefish trawlers left in the industry and about 70 purse seine boats (National Audit Office, 2020). The relatively few remaining players in these fleet segments have been allocated an institutional protected raw material market share, and they are allowed to collaborate on price setting through fisher-owned sales monopolies. In addition, incumbents are protected by high barriers to entry. In addition to extra profit being made via a favorable institutional framework (Bertheussen, 2021), these firms enjoy the value of free input of fish that has the potential to create resource rent. Unlike, for example, the processing industry, fishers do not pay for their raw materials. Such a cost item does therefore not exist in the vessels' financial accounts.

\section{NORWEGIAN PELAGIC FISHERIES}

\section{Catch Volumes and Revenues}

Figure 1 provides an overview of revenues and catch volumes taken by all Norwegian seagoing pelagic vessels during the study period.

As shown in Figure 1, the revenues from the seagoing pelagic vessel group have increased from barely 4 billion NOK in 2005 to a little more than 5 billion NOK in 2017 (as indicated in the left axis). This corresponds to an annual revenue growth rate of $2.2 \%$. Revenues were noted to peak in 2011 at 6.3 billion NOK. However, in the same period, the total catch volume of all pelagic species has declined from 1.4 billion kilograms in 2005 to 1.3 billion kilograms in 2017. This corresponds to an average annual decline in catch volume of.9\%. When revenues have increased despite a decrease in volume, this can be explained by an increase in prices of pelagic products. Part of the price increase is due to an increase in the proportion of products that go to human consumption. The fact that the Norwegian currency has depreciated relative to the dollars and the euro in recent years is another important contributor to the price increase experienced in the NOK.

\section{Fisheries Management}

Before 1970, there were no capacity-reducing measures in the Norwegian purse seine fleet (Standal, 2009). However, the crisis following the collapse of the Atlanto-Scandian herring stock in 1968-1969 led to a halt to the registration of purse seiners in 1970, the introduction of TAC for herring in 1971, and a total ban on catching Atlantic-Scandian herring in 1972 (Finstad et al., 2014). In the 1970s, more measures were introduced to reduce capacity through scrapping vessels. Furthermore, financial support for scrapping old vessels and natural retirement due to old age of crew led to a decline in purse seiners from 460 vessels in 1967 to 115 in 1991 (see Figure 2). Then the rules for permissible cargo volume for existing and new vessels were simultaneously liberalized, and, as a consequence, the reduction of total cargo capacity was significantly less than indicated by the reduction of vessels (Standal, 2009). Nevertheless, Zhang et al. (2018) found empirical support for a positive relationship between vessel capacity adjustment and vessel's profitability in the Norwegian fishing fleet.

In 1996, a system of IVQ was introduced aiming at reducing the number of vessels as the catch capacity still exceeded the available quota basis (Hersoug, 2005). Moreover, the IVQs were made tradable, and a vessel owner was able to concentrate up to two quotas per vessel (Standal, 2009). In 2000, the system was extended even further, allowing the merging of up to three quotas per vessel.

In 2005 , the IVQ system was converted into a system with so-called "structure quotas" (SQs) as an additional measure to reduce catch capacity and increase efficiency. This is a more flexible and market-oriented system than the former (Johnsen and Jentoft, 2018).

Formally, Norway does not manage its fisheries by ITQs, but in reality, the fisheries management has many similarities with such a system (e.g., Hannesson, 2013; Asche et al., 2014; Standal and Asche, 2018). An ITQ regime is based on market logic where quota transactions act as an allocation mechanism between fishing vessel firms. Accordingly, it is the firms' responsibility to adapt their quota basis to their catch capacities, as it is assumed that the firms act as rational actors that aim to maximize their profit from the given quota basis (Hannesson, 2017; Bertheussen et al., 2020).

A profound criticism of the ITQ model is that the system leads to a concentration of quota ownership (e.g., Agnarsson et al., 2016). In addition, the system has failed to emphasize the importance of securing fish resources to geographical areas that are most dependent upon fisheries (Standal and Aarset, 2008). However, restrictions can be built into an ITQ regime to prevent the market from becoming the sole quota allocation mechanism. Many quota regimes, including that of Norway's, have features aimed at protecting the social structure and division of equity, e.g., regional restrictions on trade (see Table 1). Modifications include separate markets for different regions (e.g., north/south), built-in restrictions in terms of quota concentration per vessel (or vessel group), separate markets to ensure that a variety of adaptations coexist, and a requirement that a fishing vessel firm must buy another vessel (which must be scrapped) with attached fishing rights in order to increase its own total quota share (Standal, 2009). The key features of the SQ system of Norwegian purse seiners are outlined in Table 1.

\section{DATA AND METHODS}

\section{Research Design}

The research design of an empirical study, as outlined in this article, requires in-depth knowledge of the institutions embracing the competition arena and how these expectedly will shape the profit and rent generation of the vessels. The design also requires the development of valid and reliable profit and rent performance measures. Finally, a dataset of representative vessels over a period covering the introduction 

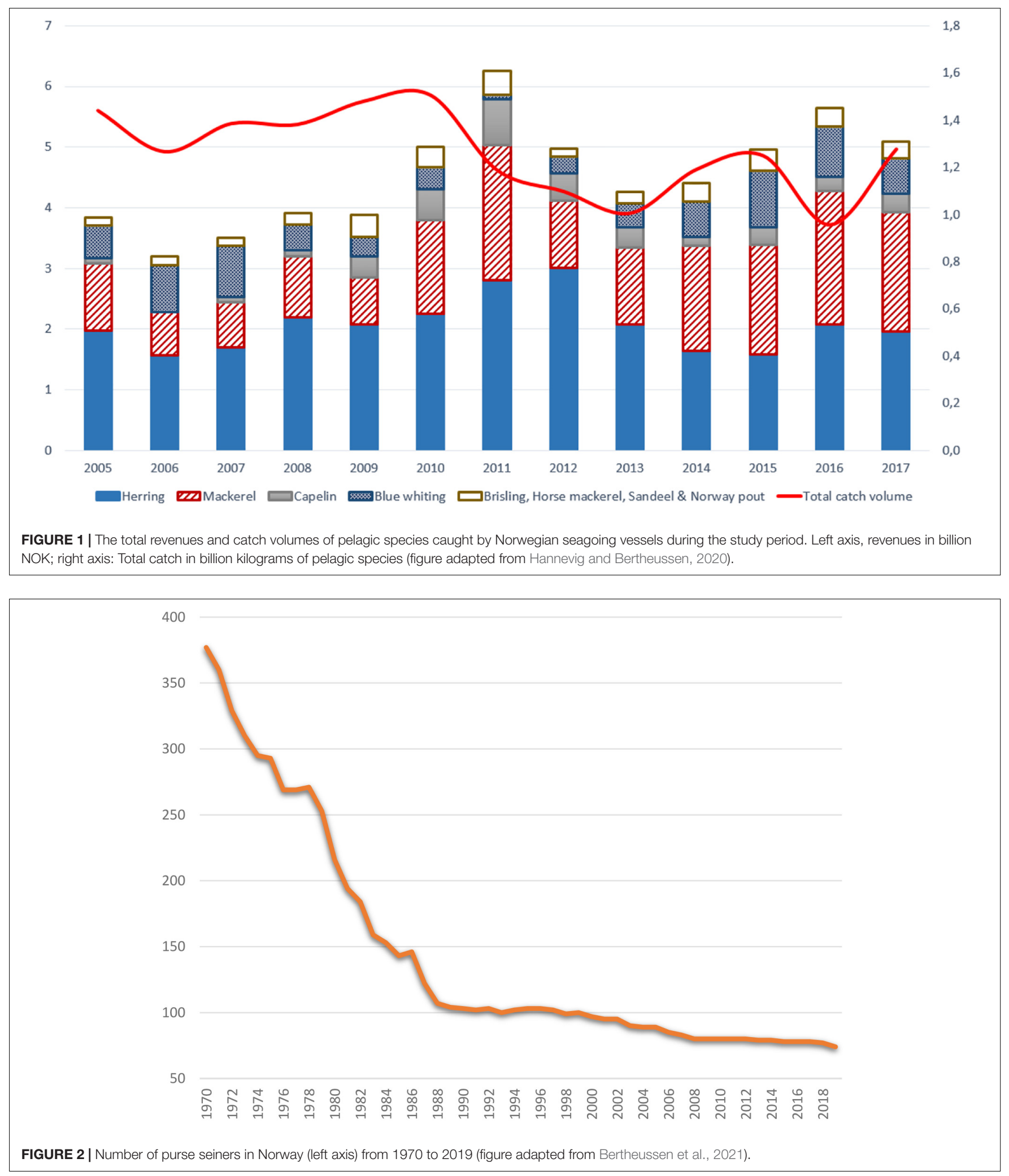

and long-term use of an ITQ-like management regime is deemed necessary. In this context, a period of 13 years (2005-2017) is considered sufficient to investigate how vessels have been able to make profit and generate rent under the Norwegian SQ system. Focusing on one single industry makes it possible to control for industry impact, which, according 
TABLE 1 | Key features of the structural quota system of Norwegian purse seiners*.

\begin{tabular}{|c|c|c|}
\hline No & Modification & Justification \\
\hline 1 & $\begin{array}{l}\text { The giving vessel has to be scrapped when quotas are transferred. Moreover, } \\
\text { quotas can only be transferred between vessels in the same group. }\end{array}$ & $\begin{array}{l}\text { The responsibility for removing overcapacity in the industry is left to the actors } \\
\text { themselves through the SQS system. }\end{array}$ \\
\hline 2 & $\begin{array}{l}\text { When a quota is transferred in the purse seine vessel group, } 5-40 \% \text {, depending } \\
\text { on the vessels' homeports, is deducted from the transaction and re-allocated to } \\
\text { the vessel group. }\end{array}$ & $\begin{array}{l}\text { To disincentive quota transfers from certain geographic regions and resulting } \\
\text { geographic concentration. Also, to slow down the use of the mechanism. }\end{array}$ \\
\hline 3 & $\begin{array}{l}\text { If the quota is traded from the northern to the southern region, it will be reduced } \\
\text { by } 40 \% \text {. If it is traded within the northern region, the reduction is only } 5 \% \text { and } \\
15 \% \text { if the trade takes place within the southern region. }\end{array}$ & \\
\hline 4 & $\begin{array}{l}\text { Each vessel has a quota ceiling of } 850 \text { tons at present, which represents } \\
\text { approximately } 2 \% \text { of the vessel group's TAC share. }\end{array}$ & To prevent too high concentration of quotas on a few vessels. \\
\hline 5 & $\begin{array}{l}\text { Each firm has a quota ceiling, which corresponds to approximately } 6.5 \% \text { of the } \\
\text { vessel group's TAC share. }\end{array}$ & To avoid overconcentration of quotas on a few firms. \\
\hline 6 & $\begin{array}{l}\text { Tradeable quotas (structural quotas) are time limited. Upon expiration, in } 2027 \\
\text { at the earliest, there is anticipation among industry actors that they will be } \\
\text { allocated to the vessels remaining in the group, even though this is not formally } \\
\text { yet determined. }\end{array}$ & To express that the fish resources are a common property. \\
\hline 7 & Quota leasing is not permitted. & \\
\hline
\end{tabular}

${ }^{\star}$ Adapted from Johnsen and Jentoft (2018) and Standal and Asche (2018).

to Porter (2008), is crucial for firms' profitability and wealthcreating potential.

\section{Unit of Analysis}

The vessel (seagoing purse seiner) is the unit of analysis in this present study. The validity of the comparison of vessels' profitability and rent generation is highest when vessels are similar (Vassdal and Bertheussen, 2020). This study, therefore, chose an industry of similar vessels, which is the Norwegian purse seiner fleet. According to the Norwegian Participation Act (2013, $\$ 6$ ), a fisherman must be actively fishing for at least three of the last 5 years to be allowed to own a fishing vessel. Consequently, all Norwegian purse seiners are owned by active Norwegian fishers or descendants of fishers. Further, to prevent concentration of quotas on a few vessels, there is a current quota ceiling for each vessel at 850 so-called base tons, ${ }^{4}$ which represents approximately $2 \%$ of the TAC share (Johnsen and Jentoft, 2018). The quota of the largest vessel is approximately twice the quota of the smallest.

\section{Sampling and Data Collection}

Fisheries management objectives generally include improving economic performance. Nevertheless, vessel data to assess this are often unavailable as relatively few fisheries managers collect such information, or they collect it only sporadically (Pascoe et al., 2019). Accordingly, there must be sufficiently detailed longitudinal financial information available to measure the profit-making and economic rent creation of the vessels. This information must also be available for a sufficient number of vessels to ensure the statistical validity of the conclusions. The Norwegian Directorate of Fisheries requires most fish vessel companies to report income and cost data annually per vessel.

\footnotetext{
${ }^{4}$ Base ton is not a physical measure, but it indicates the proportion of the vessel group's TAC that a vessel can fish of the most important species, such as mackerel, herring, and capelin. The ocean-going purse seine fleet has a total of 41,700 base tons at its disposal. This means, for example, that a vessel with a quota of 850 base tons can fish $2.04 \%(850 / 41,700)$ of the vessel group's TAC per year.
}

Furthermore, physical catch data, the number of man-years used on the vessel, the number of operating days per vessel, etc. must be reported. This study has gained access to this unique dataset and has based all its analysis on it.

The data used are individual at the vessel level. Vessel-level data include financial data like those published in "Profitability survey for the fishing fleet 2018." This is an annual publication and presents the average financial and economic results, catches, and a short general description of each group's average vessel. The detail of financial information is similar in content to the section "Accumulated results by type of fishery. Average per vessel. Table G 20." It is worth noting the difference between the published data and the data made available for this present study by the Directorate of Fisheries.

First, as mentioned above, this study has been given access to the individual vessel-level data for all vessels included in the survey. These vessels data also include technical data for each vessel (length, gross tonnage, engine horsepower, building year), all fishing licenses for each vessel, and a detailed description of vessel catch (both quantities and values).

Second, the annual survey is a sample of a larger population. The sample covers about $75-85 \%$ of the population, varying seemingly randomly from year to year. The population size was noted to have slightly decreased over the study period, from 85 vessels in 2005 to 72 in 2017. There is no noticeable change in sample representativeness over the same period (Vassdal and Bertheussen, under prep.).

Third, when a vessel enters or leaves the sample, that observation cannot be interpreted as a new built vessel entering the population or an old vessel leaving due to decommissioning. It is observed that several vessels exit and enter the sample repeatedly over the study period (ibid.). The population is

\footnotetext{
${ }^{5}$ Annual reports from Fiskeridirektoratet, Bergen, Norway, period 1998-2019, are available at: https://www.fiskeridir.no/Yrkesfiske/Tall-og-analyse/Statistiskepublikasjoner/Loennsomhetsundersoekelse-for-fiskeflaaten.
} 
dynamic, witnessed by the decrease of net 13 active vessels over the full period. The sample is also dynamic as different vessels each year are asked to participate in the survey.

Fourth, most publications examining the same or similar vessel groups over time have presented average annual results based on a sample that is very different at the end of the period compared to the beginning (e.g., Flaaten et al., 2017; Hannesson, 2017).

To control for the change in the composition of vessels over time, a cohort of vessels that belonged to the sample every year from 2005 to 2017 was selected (Vassdal and Bertheussen, under prep.). In total, $35^{6}$ such vessels were identified, and the financial accounts of these purse seiners were analyzed. The period analyzed is 13 years. Accordingly, financial accounts were collected for the years 2005-2017. The sample of 35 vessels is on average $54 \%$ of the vessels belonging to the total sample as published annually by the Directorate of Fisheries.?

By studying a balanced subsample, we have avoided the statistical and methodological "noise" and variability created by exits and entries of vessels in the full sample published by the Directorate of Fisheries (Vassdal and Bertheussen, under prep.).

\section{Measuring Profit and Rent}

This study explores the profit-making and rent generation of fishing vessels under the SQ regime. The chosen 13-year period (2005-2017) covers the implementation of the SQ system in the Norwegian pelagic fisheries, which started in 2005. It is of particular interest to study vessels' profit-making and rent generation over time in a population like this, because the adaptation process to the new regime is not necessarily rapid, and the profit- and rent-generating effects may not be instantly visible. The industry structure has been relatively stable in the study period. In such a setting, there is a need for a longterm study as prospects of uncovering the magnitude of the profit-making and rent generation that has taken place will then be better. Accordingly, we have investigated the average and cumulated profit and rent generation over this period. The outcome in any particular year may be influenced by resource variations that presumably average over a period of 13 years.

Accounting conventions can influence the numbers for return and profitability (Penman, 2013). Edwards and Bell (1961) gave a formal economic foundation for using company accounting figures in economic valuation. Feltham and Ohlson (1995) clarified the concept of "abnormal earnings from operating activities." Residual income is the term used in accounting for "abnormal earnings" translated to applicable rules in popular valuation textbooks (see, for example, Koller et al., 2010; Damodaran, 2012). Feltham and Ohlson (1995) also clarified the functions of depreciations in

\footnotetext{
${ }^{6}$ The database contained 434 of the 455 fiscal years needed to obtain complete time series for the 35 vessels during the period 2005-2017. Thus, 21 missing financial years were obtained from the companies' official accounts collected from the official Norwegian accounting register brreg.no.

${ }^{7}$ The sample is minimum $47 \%$ in 2005 and maximum 58\% in 2012-2013.

${ }^{8}$ Feltham and Ohlson (1995; endnote 1). The same footnote lists several contributions before Edwards and Bell (1961) that explored the concept of "abnormal earnings."
}

accounting within the same theoretical framework as in Edwards and Bell (1961).

Accounting information, even when following legal rules and recommendations and when audited, may be difficult to interpret and compare across companies and over time. Cash flow accounting is less susceptible to ambiguity and/or manipulations than conventional accrual accounting. Earnings before interest, taxes, depreciations, and amortizations (EBITDA) are cash flow generated from operations. Depreciations and/or amortizations have no influence on operating cash flow before taxes. The firm can thus retain and cumulate operating cash flow as current assets, but it will normally find other use of such means. Investment in operating long-term assets has been identified as an important use of operating cash flow. The average fishing vessels in this study have, for the period 2005-2017, invested approximately 35 million NOK in vessel and gear and approximately 75 million NOK in licenses (see Table 2). The numbers are calculated as book values at the end of the period minus book values at the start of the period plus cumulated depreciations over the period. Book values of quotas and vessels are summarized in Table 3.

The formula for capital expenditure (CapEx) for a specific year, $\mathrm{t}$, is as follows: CapEx $x_{t}=\left(I C_{t}-I C_{t-1}+D e p r_{t}\right) . \mathrm{IC}_{t}$ is the book value of invested capital at the end of year t. $\mathrm{IC}_{t-1}$ is invested capital in the previous year. Depr $r_{t}$ is depreciation and amortization year $t$. When $\mathrm{IC}_{t}=\mathrm{IC}_{t-1}$, capital expenditure will be equal to depreciation and amortization. Change in IC for 2005 cannot be calculated, as data for 2004 is not available. Free cash flow (FCF) is described as cash flow after deduction of capital expenditure from EBITDA. Free cash flow is fundamental for the valuation of a firm. The average vessel has accumulated FCF of approximately 100 million NOK over the examined period (see Table 2). FCF can be used to pay interest, reduce debt (in our sample average debt has actually increased), or pay taxes, be retained as current assets, or paid as dividends to equity holders. Exactly how FCF is used after being created is not the topic of this paper.

To calculate the rent generation of the vessels, this study calculates RI based on cash flow from operations, cash flow from investment, and net FCF. The risk-adjusted capital cost, $k$, can be calculated as the textbook weighted average cost of capital (WACC). As clarified by Miles and Ezzell (1980) and building on Modigliani and Miller (1958), assumptions behind WACC are not normally met. The formula requires market value of equity; however, only the book value is known. The relative market value of debt relative to equity cannot be assumed to be stable over time, as presumed in the formula. The systematic risk for equity and debt cannot be estimated from equity markets because none of the firms in the study is traded on open stock markets. Accordingly, a constant annual nominal pre-tax discount rate of $6 \%$ is used. Thus, the theoretical correct riskadjusted cost of capital may differ from the choice of discount rate used in this study.

The cost of capital for the economy may differ from the cost of capital for a firm or a private investor. There are, however, some guidelines that may support our choice. The Official Norwegian 
TABLE 2 | Cash flow and residual income of the 35-vessel cohorta.

\begin{tabular}{|c|c|c|c|c|c|c|c|c|}
\hline Year & EBITDA & Cumulative EBITDA & Capex quotas only & Capex vessels, gear, etc. & FCF $^{b}$ & Cumulative FCF & $\mathbf{R I}$ & Cumulative RI \\
\hline 2005 & 15,704 & 15,704 & & & & & & \\
\hline 2006 & 12,691 & 28,395 & 11,026 & 7,995 & $-6,329$ & $-6,329$ & 3,913 & 3,913 \\
\hline 2007 & 13,271 & 41,666 & 10,949 & 4,697 & $-2,375$ & $-8,704$ & 3,668 & 7,581 \\
\hline 2008 & 16,590 & 58,256 & 10,917 & 284 & 5,389 & $-3,315$ & 4,362 & 11,943 \\
\hline 2009 & 15,610 & 73,866 & 1,703 & $-1,763$ & 15,670 & 12,355 & 3,575 & 15,518 \\
\hline 2010 & 19,964 & 93,830 & 88 & 1,593 & 18,282 & 30,637 & 8,885 & 24,403 \\
\hline 2011 & 28,033 & 121,863 & 17 & 3,500 & 24,517 & 55,154 & 16,258 & 40,661 \\
\hline 2012 & 18,893 & 140,756 & 5,935 & 6,756 & 6,202 & 61,356 & 7,657 & 48,318 \\
\hline 2013 & 15,611 & 156,367 & 5,306 & 1,687 & 8,618 & 69,974 & 3,822 & 52,140 \\
\hline 2014 & 14,436 & 170,803 & 4,907 & 16,002 & $-6,473$ & 63,501 & 2,372 & 54,512 \\
\hline 2015 & 16,014 & 186,818 & 4,374 & 4,280 & 7,360 & 70,861 & 3,348 & 57,860 \\
\hline 2016 & 22,945 & 209,763 & -940 & 7,418 & 16,467 & 87,328 & 9,896 & 67,756 \\
\hline 2017 & 17,705 & 227,468 & 20,986 & $-16,799$ & 13,519 & 100,847 & 5,184 & 72,940 \\
\hline Average & 17,497 & & 6,272 & 2,971 & 8,404 & & 6,078 & \\
\hline
\end{tabular}

${ }^{a}$ All numbers are in 1,000 NOK.

${ }^{b}$ The FCF calculation does not consider changes in working capital; this means that the FCF is a little too high.

TABLE 3 | Summary of average accounting figures for the 35-vessel cohort. All accounting numbers are in nominal 1,000 NOK*.

\begin{tabular}{|c|c|c|c|c|c|c|c|c|c|c|c|c|c|}
\hline Year & Sample & Revenues & $\begin{array}{c}\text { Operating } \\
\text { profit }\end{array}$ & $\begin{array}{c}\text { Net profit } \\
\text { before taxes }\end{array}$ & $\begin{array}{c}\text { Depr. and } \\
\text { amort. }\end{array}$ & $\begin{array}{l}\text { Book value } \\
\text { fish licenses }\end{array}$ & $\begin{array}{c}\text { Book value } \\
\text { vessels }\end{array}$ & Equity & $\begin{array}{l}\text { Total } \\
\text { debt }\end{array}$ & $\begin{array}{l}\text { Base } \\
\text { quota }\end{array}$ & $\begin{array}{c}\text { Structural } \\
\text { quota }\end{array}$ & ROA & ROE \\
\hline 2005 & 35 & 40,473 & 11,300 & 9,711 & 4,404 & 8,595 & 57,769 & 27,310 & 76,481 & 433 & 69 & & \\
\hline 2006 & 35 & 36,289 & 8,539 & 7,998 & 4,152 & 19,586 & 58,378 & 34,741 & 82,002 & 433 & 74 & $7.3 \%$ & $23.0 \%$ \\
\hline 2007 & 35 & 39,839 & 9,187 & 9,011 & 4,084 & 30,444 & 52,331 & 41,593 & 91,460 & 434 & 72 & $6.9 \%$ & $21.7 \%$ \\
\hline 2008 & 35 & 44,289 & 10,575 & 5,687 & 6,015 & 39,791 & 52,211 & 39,848 & 97,521 & 434 & 99 & $7.7 \%$ & $14.3 \%$ \\
\hline 2009 & 35 & 43,176 & 10,099 & 8,950 & 5,512 & 39,933 & 48,378 & 42,247 & 89,564 & 434 & 100 & $7.7 \%$ & $21.2 \%$ \\
\hline 2010 & 35 & 51,204 & 15,074 & 13,299 & 4,890 & 38,377 & 45,757 & 44,991 & 90,703 & 434 & 100 & $11.1 \%$ & $29.6 \%$ \\
\hline 2011 & 35 & 63,427 & 22,255 & 20,091 & 5,778 & 36,730 & 42,002 & 51,295 & 91,018 & 434 & 100 & $15.6 \%$ & $39.2 \%$ \\
\hline 2012 & 35 & 48,243 & 13,518 & 11,809 & 5,375 & 41,140 & 39,824 & 57,166 & 87,050 & 434 & 100 & $9.4 \%$ & $20.7 \%$ \\
\hline 2013 & 35 & 44,121 & 10,122 & 7,997 & 5,489 & 44,664 & 41,840 & 58,406 & 97,866 & 430 & 107 & $6.5 \%$ & $13.7 \%$ \\
\hline 2014 & 35 & 44,923 & 8,762 & 7,037 & 5,674 & 47,876 & 36,207 & 59,196 & 99,915 & 425 & 99 & $5.5 \%$ & $11.9 \%$ \\
\hline 2015 & 35 & 49,026 & 10,652 & 7,376 & 5,262 & 50,550 & 34,071 & 57,307 & 99,746 & 425 & 102 & $6.8 \%$ & $12.9 \%$ \\
\hline 2016 & 35 & 56,571 & 17,398 & 17,499 & 5,547 & 47,598 & 31,065 & 63,970 & 104,606 & 423 & 103 & $10.3 \%$ & $27.4 \%$ \\
\hline 2017 & 35 & 50,403 & 12,741 & 10,001 & 4,964 & 66,796 & 30,761 & 72,634 & 110,412 & 423 & 103 & $7.0 \%$ & $13.8 \%$ \\
\hline Average & 35 & 47,076 & 12,325 & 10,497 & 5,173 & 39,391 & 43,892 & 50,054 & 93,719 & 430 & 94 & $8.5 \%$ & $20.8 \%$ \\
\hline
\end{tabular}

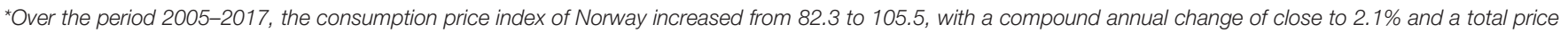

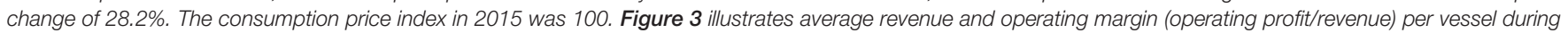
the study period.

Report (NOU [2012: 16], 2012) ${ }^{9}$ states on p. 75 that: "For use in socio-economic analysis of a normal public measure, such as a transport measure, a real risk-adjusted discount rate of 4 per cent will be reasonable for effects in the first 40 years from the time of analysis" (authors translation). That is, a risk-adjusted discount rate should be about $4 \%$ for public infrastructure projects before adjusting for price-level changes. If the annual change in price level is about $2 \%$, then the nominal discount rate will be about $6 \%$.

The guidelines from the Norwegian Directorate for Financial Management (Direktoratet for økonomistyring, 2014, p. 92) recommends the same $4 \%$ real discount rate for investment with a life span of less than 40 years, but with the following reservation: "For government business operations in direct competition with

${ }^{9}$ https://www.regjeringen.no/no/dokumenter/nou-2012-16/id700821/ private actors, a discount rate corresponding to that faced by private companies shall be used" (authors translation).

Thus, $6 \%$ annual nominal rate for the total cost of capital seems to be in the lower range of possible rates. Also, recent market observations have demonstrated that the almost risk-free interest rate determined by the market for long-term government bonds may vary considerably. The annual rate in 2020 for 10 years Norwegian government bonds was about $0.8 \%$ but has recently increased. In November 2021 average daily rates for 10 years government bonds were $1.6 \%$. Ten years ago, government bonds with 10 years of maturity had an average annual rate of $3.5 \%$; 20 years ago, $6.7 \%$; and 30 years ago, $10.7 \% .^{10}$

\footnotetext{
${ }^{10} \mathrm{https} / / /$ www.norges-bank.no/tema/Statistikk/Rentestatistikk/StatsobligasjonerRente-Arsgjennomsnitt-av-daglige-noteringer/
} 

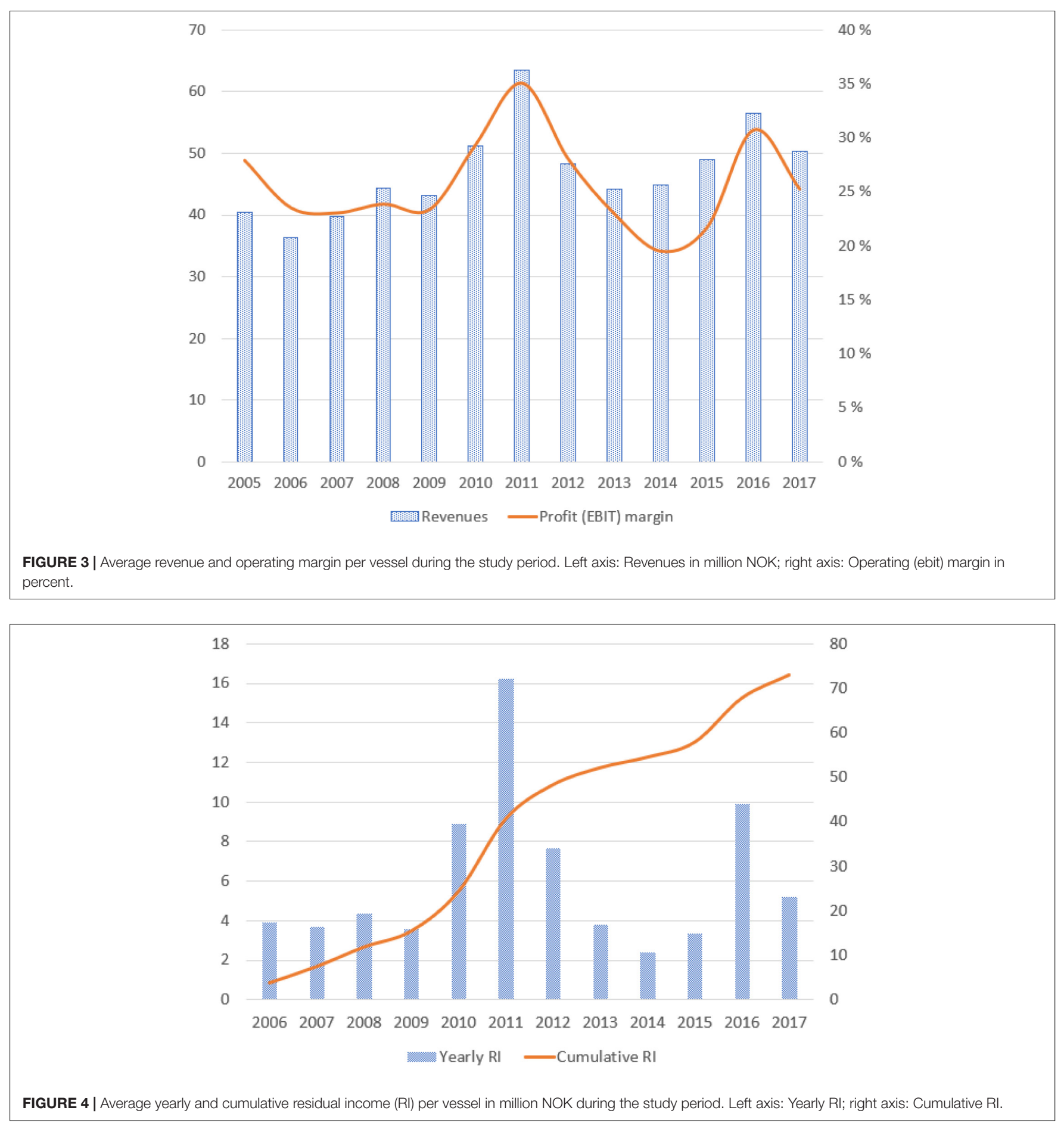

Some scholars (e.g., Flaaten et al., 2017) argue that financing decisions at the firm level influence profitability and resource rent creation. The ROE is influenced by financing decisions at the firm level. A high debt/equity ratio will increase the nominal ROE, given that the return on assets is larger than the cost of debt. However, a high debt/equity ratio will also lead to larger variability in ROE than a low debt/equity ratio. From the theory of corporate finance, the conclusion is that there is a balance between return and risk. This is explained in the capital asset pricing model. This theory has two critical implications. First, there is no optimal debt/equity ratio for most firms, and second, investment decisions and financing decisions should be considered separately and independently. This present study has followed the mainstream of financial theory on the debt/equity issue and concluded that the debt/equity ratio does not influence the total operating assets' return. The choice of financing is in the 
realm of the owner of a firm and has no general consequence for the economic analysis of this and most other sectors, including the fisheries. The return on operating assets is essential for the economy. The debt/equity ratio and $\mathrm{ROE}$ is important for the owner but is basically an issue of distributing, not creating, the operating return among stakeholders.

\section{EMPIRICAL FINDINGS}

In this section, we present the empirical findings of this study. Table 3 provides a summary of average accounting figures for the 35-vessel cohort under study. Revenues, operating profit, and net profit before taxes are noted to be remarkably stable over time, although with some natural variations (see Figure 1). The best years in financial terms are 2011 and 2016. The book value of fish licenses increased remarkably from 2005 to 2008, closely following the introduction of the SQ system in 2005. Thereafter, the change has been more modest except for the sharp increase from 2016 to 2017 . The book value of vessels has declined steadily due to depreciation. However, some minor investments in vessels and gear may balance depreciation for occasional years. The book value of equity has more than doubled over the period (166\%), whereas the debt has increased close to the increase in the general price level. The minimum return on assets (ROA) was $5.5 \%$ in 2014 , whereas the maximum was $15.6 \%$ in 2011 . The average was $8.5 \%$ for the period studied. The average ROE was $20.8 \%$. The calculated ROA and ROE are before taxes.

The RQ raised in this study was as follows:

RQ: To what degree have the purse seiners that were present in the industry in 2005 been able to generate rent during the period in which the SQ system has been in operation?

As outlined in paragraph 3.4, estimating proper RI is the method used in this paper to measure above-normal earnings, that is, rent generation (Feltham and Ohlson, 1995). Magni (2009) listed approximately 30 synonyms presently and formerly used in economics and accounting literature for the same concept. The formula for RI (before taxes) is operating profit (before taxes) less calculated cost of invested capital. Only tangible assets and intangible assets are included in invested capital. Thus, current assets are not included. The cost of capital, $k$, for the RI calculations in Table 2 is $6 \%$. RI is sensible for the choice of capital cost. Higher cost of capital, i.e., $k=10 \%$, will lead to negative RI in 5 out of 12 years, as shown in Table 2. Cumulated RI is still positive if $\mathrm{k}=10 \%$. Cumulative RI is rent over a defined period for an average vessel when book value of licenses is also included in the capital stock. Table 2 presents the detailed findings.

The EBITDA column shows the average cash flow from operations per vessel. EBITDA is approximately 17.5 million NOK on average. Cash flow from operations is positive and quite stable every year, except for 2011 and 2016, which stood out positively. Annual Capex for quotas and vessels/gear fluctuate more. These variations spill over on FCF. For 3 years (2006, 2007, and 2014), FCF was noted to be negative. Nevertheless, cumulated FCF for year 2017 is approximately 101 million NOK per vessel. It is well known from standard valuation textbooks (i.e., Koller et al., 2010; Damodaran, 2012; Penman, 2013), that discounted future FCF determines the fundamental value of an investment. However, this study does not make any effort to estimate FCF after 2017, as it failed to discount FCF over the total lifespan of an average vessel in the cohort.

RI is reported annually from 2006 to 2017 and cumulated. Cumulated RI to 2017 is approximately 73 million NOK. Discounted RI is a good indication of "hidden values" in the balance sheet. Discounted value of RI for the period 2006-2017 is approximately 50 million NOK per vessel. Table 3 indicates that book value in 2005 for quota and vessels were 66.4 million NOK, whereas for vessels alone, it was approximately 58 million NOK. The present value of RI is calculated after considerable investment in quotas has been made. Capex for quota and licenses over the period have been 75 million NOK per vessel, which is the cumulative of annual "Capex Quotas only" column in Table 2. For the average vessel, the present value of resource rent (RI) is approximately 50 million NOK per vessel. The 50 million NOK is the "hidden value" of main quotas when entering the period of the new SQ system. Not included in the calculation is the present value of potential RI that may originate after 2017. Yearly and cumulative RI is illustrated in Figure 4.

\section{DISCUSSION}

This paper has empirically examined the long-term profitability and rent generation of fishing vessels that had taken place during a period (2005-2017) that saw the implementation of the Norwegian ITQ variant, or the so-called SQ system. The context was a cohort of 35 Norwegian seagoing pelagic fishing vessels that constitute approximately half of the population.

Table 3 summarizes the accounting figures of the vessels during the first 13 years after the introduction of the SQ regime. The figures draw a picture of a very stable and profitable industry. This is especially true for the development in revenues (also, see Figure 1) and operating profit. Further, the average ROA was $8.5 \%$ during the 13 -year period, whereas ROE on average was formidable at $20.8 \%$. The findings support the claim made in the introduction part of the paper that the economic attractiveness of a fishing industry is influenced by its biological and institutional environment. Surroundings that provide exclusive rights to vessels to harvest a valuable and common fish resource for free (see Base Quota column in Table 3) have put a very good foundation in place for profitable operations and rent generation of the players. These findings are consistent with findings of Bertheussen and Vassdal (2019).

Furthermore, Table 3 indicates that most of the quota trading took place in the very first years after the SQ system was introduced in 2005. The average holding of so-called structural quotas increased from 69 quota units in 2005 to 99 in 2008. Simultaneously, the value of fish licenses that entered the books increased from 8.6 million NOK in 2005 to 39.8 million NOK in 2008. Thus, the average book price of a quota was $124,000 \mathrm{NOK}$ in $2005(8,595 / 69)$, whereas the average book price of an added 
quota unit in the period 2006-2008 was $(39,791-8,595) /(99$ $69)=1,040,000$ NOK. This represents a price increase of a quota unit of $739 \%$ during the very first years of the SQ system. In this Norwegian pelagic case, the strongest effect on quota trading volume and quota price development of introducing a regulatory change occurred immediately after the rule change took place. It is also worth noting how robust the income and profitability were for the sample during the financial crisis that took place in 2007-2008 (see Table 3).

The RQ raised in this study was: "To what degree have the purse seiners been able to generate rent during the period, which the SQ system has been in operation?" In market-oriented competitive industries, it is expected that the earnings of the players over time will correspond to the alternative cost of capital. Accordingly, the average firm will not generate RI or rent. However, the findings of this present study indicate that the vessels were able to generate substantial rent (see Table 2). For the cohort of 35 vessels, RI was reported for every year examined (2006-2017). Thus, the average cumulative current RI of a vessel in the cohort during the 12-year calculation period was approximately 73 million NOK. Each of the 35 vessels, on average, generated FCF of 101 million NOK in the study period. Present value calculation confirms the rent generation accruing to the vessel owners. The discounted value of RI for the period was approximately 50 million NOK per vessel. This implies that considerable rent, i.e., superprofit, was generated in this industry.

\section{Implications}

This study has taken the perspectives of an industry, and incumbent vessels are used as the unit of analysis. The fact that no resource rent tax has been introduced in Norway is thus positive for both industry attractiveness and incumbent firms' profitability and rent generation (Bertheussen and Vassdal, 2021). However, this view of resource rent taxation may be different from the perspective of society.

The financial performance of the Norwegian pelagic fish capturing industry is better than in most other Norwegian business sectors. This scenario may be attributed to several factors. For one, society provides the participants with gratis input of common valuable natural resources. Another reason is that society implicitly allows the industry to operate under very favorable business framework conditions. High institutional and financial barriers to entry protect the fish vessel owners from outside competition (Bertheussen et al., 2021), individual quota shares protect the players from internal rivalry (Birkenbach et al., 2017), and fisher-owned sales monopolies empower the industry vs. fish buyers. It can thus be argued from the perspective of society that the Norwegian SQ system, in line with most other ITQ variants in the world (Hoshino et al., 2019), has a "soft spot" because of the absence of institutions that can tax and redistribute some of the rent being generated.

When the resource rent generated is not collected by society, which is the formal owner of the resource and the regulator of the fishery, its value accrues to the vessel owners and the fishers in the form of rent and above-normal wages. In this sense, the rent being generated is allocated to only two stakeholders of society (Coglan and Pascoe, 1999). Accordingly, it does not seem unreasonable to propose that a rent tax should be introduced in Norwegian fisheries to obtain more equitable distribution of the significant values being created (Cunningham et al., 2009). This has, for example, been done in Iceland (Gunnlaugsson et al., 2018).

In natural resource-based industries, several stakeholders collectively provide resources to the bundle required to generate economic values (Bertheussen and Vassdal, under review). In a rights-based fishery, some key stakeholders are outside the boundaries of the firm. This applies, for example, to society that owns the natural resource and the government that controls the extraction of the renewable resource through its fisheries management system. Accordingly, the economic values created should, in principle, be distributed relative to the contributions of the different stakeholders even if this can be hard to estimate precisely (Lippman and Rumelt, 2003; Barney, 2018). Barney (2018) further argues that in a business context, a fair distribution among key stakeholders is a prerequisite to maintain the resource bundle, and thus, the rent-generating potential in the long run.

\section{Limitations}

The fishing vessels sector is dynamic. Old vessels are scrapped, and new vessels that are more expensive take their place. This study has followed a stable cohort of 35 existing vessels from 2005 to 2017. Inevitably, the vessels have aged; this may have consequences for the profitability measures through the influence of vessel depreciations. Normally, the vessels practice linear depreciation. A consequence is that the time profile of the rate of return will be predictably different from the internal rate of return for an investment. Such investments will appear more profitable late in the economic lifespan than in the early years. Also, the standard accounting methods for profitability calculations may underestimate the effect of inflation. Both these effects may make the sample to appear more profitable than a similar new vessel built after 2005 .

\section{DATA AVAILABILITY STATEMENT}

The data analyzed in this study is subject to the following licenses/restrictions: The Norwegian Directorate of Fisheries has provided the data utilized by the present study based on an agreement with the authors that the data set will not be published. Requests to access these datasets should be directed to AnetteEllefsen.

\section{AUTHOR CONTRIBUTIONS}

Both authors listed have made a substantial, direct, and intellectual contribution to the work, and approved it for publication.

\section{FUNDING}

The publication charges for this article have been funded by the UiT The Arctic University of Norway. 


\section{REFERENCES}

Agnarsson, S., Matthiasson, T., and Giry, F. (2016). Consolidation and distribution of quota holdings in the Icelandic fisheries. Mar. Policy 72, 263-270.

Åm, H. (2021). A critical policy study on why introducing resource rent taxation in Norwegian salmon aquaculture failed. Mar. Policy 131:104692. doi: 10.1016/ j.marpol.2021.104692

Arnason, R. (2008). Iceland's ITQ system creates new wealth. Electron. J. Sustain. Dev. 1, 35-41.

Asche, F., Bjørndal, M. T., and Bjørndal, T. (2014). Development in fleet fishing capacity in rights-based fisheries. Mar. Policy 44, 166-171. doi: 10.1016/j. marpol.2013.08.018

Barney, J. B. (1991). Firm resources and sustained competitive advantage. J. Manag. 17, 99-120. doi: 10.1177/014920639101700108

Barney, J. B. (2018). Why resource-based theory's model of profit appropriation must incorporate a stakeholder perspective. Strat. Manag. J. 39, 3305-3325. doi: $10.1002 / \mathrm{smj} .2949$

Bertheussen, B. A. (2021). Sustained competitive advantage based on industryspecific institutional frameworks. Front. Mar. Sci. 8:697936. doi: 10.3389/fmars. 2021.697936

Bertheussen, B. A. (2022). Role of path-dependent institutions in rebuilding of a collapsed fishery. Mar. Policy 136:104944. doi: 10.1016/j.marpol.2021.104944

Bertheussen, B. A., Dreyer, B. M., Hermansen, $\varnothing$, and Isaksen, J. R. (2021). Institutional and financial entry barriers in a fishery. Mar. Policy 123:104303. doi: 10.1016/j.marpol.2020.104303

Bertheussen, B. A., and Vassdal, T. (2019). Strategic sources of superprofit in a well-regulated fishery. Mar. Policy 106:103551. doi: 10.1016/j.marpol.2019. 103551

Bertheussen, B. A., and Vassdal, T. (2021). Institution-based roots to fishing vessels profitability. Mar. Policy 123:104286. doi: 10.1016/j.marpol.2020.104286

Bertheussen, B. A., Xie, J., and Vassdal, T. (2020). Strategic investments in catch capacity and quotas: how costly is a mismatch for a firm? Mar. Policy 117:103874. doi: 10.1016/j.marpol.2020.103874

Birkenbach, A. M., Kaczan, D. J., and Smith, M. D. (2017). Catch shares slow the race to fish. Nature 544:223. doi: 10.1038/nature21728

Byrne, C., Agnarsson, S., and Davidsdottir, B. (2019). Profit and rent in the Icelandic harvesting sector. Fish. Res. 220:105349.

Coglan, L., and Pascoe, S. (1999). Separating resource rents from intra-marginal rents in fisheries' economic survey data. Agric. Resour. Econ. Rev. 28, 219-228. doi: $10.1017 / \mathrm{s} 1068280500008212$

Costello, C., Gaines, S. D., and Lynham, J. (2008). Can catch shares prevent fisheries collapse? Science 321, 1678-1681. doi: 10.1126/science.1159478

Cunningham, S., Neiland, A. E., Arbuckle, M., and Bostock, T. (2009). Wealthbased fisheries management: using fisheries wealth to orchestrate sound fisheries policy in practice. Mar. Resour. Econ. 24, 271-287. doi: 10.1086/mre. 24.3.42629655

Damodaran, A. (2012). Investment Valuation: Tools and Techniques for Determining the Value of Any Asset. New York, NY: Wiley Finance.

Dietz, T., Ostrom, E., and Stern, P. C. (2003). The struggle to govern the commons. Science 302, 1907-1912. doi: 10.1126/science.1091015

Direktoratet for økonomistyring (2014). Veileder i Samfunnsøkonomiske Analyser [In Norwegian: Guide in socio-Economic Analyzes]. Bergen: Fagbokforlaget Vigmostad and Bjørke AS.

Edwards, E. O., and Bell, P. W. (1961). The Theory and Measurement of Business Income. California: University of California Press.

Feltham, G. A., and Ohlson, J. A. (1995). Valuation and clean surplus accounting for operating and financial activities. Contemp. Acc. Res. 11, 689-731. doi: 10.1111/j.1911-3846.1995.tb00462.x

Finstad, B.-P., Kolle, N., and Kristiansen, A. (2014). Norges Fiskeri- Og Kysthistorie: En Naering i Omforming: 1880-1970 [Norway's Fishing and Coastal History, Volume 3: An Industry in Transformation: 1880-1970], Vol. 3. Bergen: Fagbokforlaget.

Flaaten, O. (2021). The rise and decline of fishing industry support-with a translation from Norwegian of Bjørn S. Brochmann's 1981 article 'long-term effects of government support to the fisheries. Mar. Policy 126:104112. doi: 10.1016/j.marpol.2020.104112

Flaaten, O., Heen, K., and Matthíasson, T. (2017). Profit and resource rent in fisheries. Mar. Resour. Econ. 32, 311-328. doi: 10.1086/692074
Fuglestad, E. M., and Almås, R. (2021). Tilbake til grunnrentelandet-ei idehistoriusk utgreiing om grunnrenteskatt som prinsipp [Back to the ground rent country-an idea historical study of ground rent tax as a principle]. Nytt Norsk Tidsskrift 3, 208-218. doi: 10.18261/issn.1504-3053-2021-03-04

Gordon, H. S. (1954). The economic theory of a common-property resource: the fishery. J. Politic. Econ. 62, 124-142.

Grafton, R. Q. (1996). Individual transferable quotas: theory and practice. Rev. Fish Biol. Fish. 6, 5-20. doi: 10.1007/bf00058517

Greaker, M., Grimsrud, K., and Lindholt, L. (2017). The potential resource rent from Norwegian fisheries. Mar. Policy 84, 156-166. doi: 10.1016/j.marpol.2017. 07.014

Gunnlaugsson, S. B., and Agnarsson, S. (2019). Late arrival: the development of resource rent in Icelandic fisheries. Fish. Res. 214, 126-135. doi: 10.1016/j. fishres.2019.02.007

Gunnlaugsson, S. B., Kristofersson, D., and Agnarsson, S. (2018). Fishing for a fee: resource rent taxation in Iceland's fisheries. Ocean Coast. Manag. 163, 141-150. doi: 10.1016/j.ocecoaman.2018.06.001

Hannesson, R. (2013). Norway's experience with ITQs. Mar. Policy 37, 264-269. doi: 10.1016/j.marpol.2012.05.008

Hannesson, R. (2017). Fish quota prices in Norway. Mar. Resour. Econ. 32, 109-117. doi: 10.1086/689190

Hannevig, H., and Bertheussen, B. A. (2020). The exploitation-exploration dilemma of fishing vessels with institutionally protected quota shares. Front. Mar. Sci. 7:436. doi: 10.3389/fmars.2020.00436

Hardin, G. (1968). The tragedy of the commons. Science 162, 1243-1248.

Hersoug, B. (2005). Closing the Commons: Norwegian Fisheries Management from Open Access to Private Property. The Hague: Eburon.

Hersoug, B., Finstad, B.-P., and Christensen, P. (2015). The system of Norwegian fish sales unions-An anachronism or a successful adaptation to modern fisheries? Acta Boreal. 32, 190-204. doi: 10.1080/08003831.2015.108 9670

Holm, P. (1995). The dynamics of institutionalization: transformation processes in Norwegian fisheries. Admin. Sci. Q. 40, 398-422. doi: 10.2307/239 3791

Holm, P., Finstad, B.-P., and Christensen, P. (2014). “Aldri mer 18. april!” ["Never again april 18!”], in Havet, Fisken og Oljen. Norges Fiskeri- og Kysthistorie, Vol. IV, ed. P. Christensen (Trondheim: Fagbokforlaget), 185-213.

Hoshino, E., van Putten, I., Pascoe, S., and Vieira, S. (2019). Individual transferable quotas in achieving multiple objectives of fisheries management. Mar. Policy 113:103744. doi: 10.1016/j.marpol.2019.103744

Isaksen, J. R. (2007). Upstream Vertical Integration and Financial Performance: the Case of the Norwegian Fish Processing Industry. Ph.D. thesis. Tromsø: Norwegian College of Fishery Science, University of Tromsø.

Jentoft, S. (2004). Institutions in fisheries: what they are, what they do, and how they change. Mar. Policy 28, 137-149. doi: 10.1016/s0308-597x(03)00085-x

Jentoft, S., and Finstad, B. P. (2018). Building fisheries institutions through collective action in Norway. Marit. Stud. 17, 13-25. doi: 10.1007/s40152-0180088-6

Johnsen, J. P., and Jentoft, S. (2018). “Transferable quotas in Norwegian fisheries," in Fisheries, Quota Management and Quota Transfer: Rationalization Through Bio-Economics, ed. G. M. Winder (Cham: Springer International Publishing), 121-139. doi: 10.1073/pnas.1716545115

Koller, T., Goedhart, M., and Wessels, D. (2010). Valuation: Measuring and Managing the Value of Companies. Hoboken, NJ: John Wiley \& Sons.

Lippman, S. A., and Rumelt, R. P. (2003). A bargaining perspective on resource advantage. Strat. Manag. J. 24, 1069-1086. doi: 10.1111/j.1467-9280.2008. 02096.x

Magni, C. A. (2009). Splitting up value: a critical review of residual income theories. Eur. J. Operat. Res. 198, 1-22. doi: 10.1016/j.ejor.2008.09.018

Miles, J. A., and Ezzell, J. R. (1980). The weighted average cost of capital, perfect capital markets, and project life: a clarification. J. Finan. Quant. Analys. 15, 719-730. doi: 10.2307/2330405

Mirrlees, J., Adam, S., Besley, T., Blundell, R., Bond, S., Chote, R., et al. (2011). Tax by Design. Oxford: Oxford University Press.

Modigliani, F., and Miller, M. H. (1958). The cost of capital, corporation finance and the theory of investment. Am. Econ. Rev. 48, 261-297.

Moses, J. W., and Letnes, B. (2017). Managing Resource Abundance and Wealth: The Norwegian Experience. Oxford: Oxford University Press. 
National Audit Office (2020). Riksrevisjonens Undersøkelse Av Kvotesystemet I Kyst$\mathrm{Og}$ Havfisket [The Investigation of the National Audit Office of the Quota System in Coastal and Marine Fisheries]. Riksrevisjonen: Dokument 3:6 (2019-2020).

Nielsen, M., Andersen, P., Ravensbeck, L., Laugesen, F., Kristófersson, D. M., and Ellefsen, H. (2017). Fisheries management and the value chain: the Northeast Atlantic pelagic fisheries case. Fish. Res. 186, 36-47. doi: 10.1016/j.fishres.2016. 08.004

North, D. C. (1990). Institutions, Institutional Change, and Economic Performance. Cambridge: Cambridge University Press.

NOU [2012: 16] (2012). Samfunnsøkonomiske Analyser [Socio-Economic Analyzes]. Available online at: https://www.regjeringen.no/no/dokumenter/nou-2012-16/ id700821/ (accessed November 15, 2021).

NOU [2019: 18] (2019). Skattlegging av Havbruksvirksomhet [Taxation of Aquaculture Activities]. Available online at: https://www.regjeringen.no/no/ dokumenter/nou-2019-18/id2676239/ (accessed October 15, 2021).

Pascoe, S., Giles, N., and Coglan, L. (2019). Extracting fishery economic performance information from quota trading data. Mar. Policy 102, 61-67. doi: 10.1016/j.marpol.2019.02.002

Penman, S. H. (2013). Financial Statement Analysis and Equity Valuation. Boston: McGraw-Hill.

Porter, M. E. (2008). The five competitive forces that shape strategy. Harv. Bus. Rev. $86,25-40$.

Sanders, A. R. D., Sandvik, P. T., and Storli, E. (2016). Dealing with globalisation: the nordic countries and inward FDI, 1900-1939. Bus. Hist. 58, 1210-1235.

Sogn-Grundvåg, G., Zhang, D., and Iversen, A. (2019). Large buyers at a fish auction: the case of the Norwegian pelagic auction. Mar. Policy 104, 232-238.

Standal, D. (2009). Unlocking the Concept of Capacity in Modern Fisheries Management. Ph.D. thesis. Ås, NO: Norwegian University of Life Sciences, 102.

Standal, D., and Aarset, B. (2008). The IVQ regime in Norway: a stable alternative to an ITQ regime? Mar. Policy 32, 663-668. doi: 10.1016/j.marpol.2007.11.007
Standal, D., and Asche, F. (2018). Hesitant reforms: the Norwegian approach towards ITQ's. Mar. Policy 88, 58-63.

Summers, L. H. (1987). "Investment incentives and the discounting of depreciation allowances," in The Effects of Taxation on Capital Accumulation, ed. M. Feldstein (Chicago, IL: University of Chicago Press), 295-304.

Vassdal, T., and Bertheussen, B. A. (2020). Methodological issues in estimating the profit of the core catch business unit of a fishing vessel firm. MethodsX 7:100990. doi: 10.1016/j.mex.2020.100990

Vatn, A. (2005). Institutions and the Environment. Cheltenham: Elgar.

Zhang, D., Sikveland, M., and Hermansen, $\varnothing$ (2018). Fishing fleet capacity and profitability. Mar. Policy 88, 116-121. doi: 10.1016/j.marpol.2017. 11.017

Conflict of Interest: The authors declare that the research was conducted in the absence of any commercial or financial relationships that could be construed as a potential conflict of interest.

Publisher's Note: All claims expressed in this article are solely those of the authors and do not necessarily represent those of their affiliated organizations, or those of the publisher, the editors and the reviewers. Any product that may be evaluated in this article, or claim that may be made by its manufacturer, is not guaranteed or endorsed by the publisher.

Copyright $\odot 2022$ Bertheussen and Vassdal. This is an open-access article distributed under the terms of the Creative Commons Attribution License (CC BY). The use, distribution or reproduction in other forums is permitted, provided the original author(s) and the copyright owner(s) are credited and that the original publication in this journal is cited, in accordance with accepted academic practice. No use, distribution or reproduction is permitted which does not comply with these terms. 